\title{
IDENTIFIKASI LIMBAH PERTANIAN DAN PERKEBUNAN SEBAGAI BAHAN PAKAN INKONVENSIONAL DI BANYUWANGI
}

\section{Identification of Agricultural and Plantation Byproducts as Inconventional Feed Nutrition in Banyuwangi}

\author{
Bodhi Agustono $^{1 *}$, Mirni Lamid ${ }^{1}$, Anwar Ma'ruf', Muhammad Thohawi Elziyad \\ Purnama ${ }^{3}$ \\ ${ }^{1}$ Departemen Peternakan, \\ ${ }^{2}$ Departemen Ilmu Kedokteran Dasar, \\ ${ }^{3}$ Departemen Anatomi Veteriner, \\ Fakultas Kedokteran Hewan, Universitas Airlangga, \\ Kampus C Mulyorejo, Surabaya, Jawa Timur, Indonesia, 60115 \\ Telp.(031) 5993016, Fax.(031) 5990315 \\ *Corresponding author: bodiagustono.drh@gmail.com
}

\begin{abstract}
Abstrak
Penelitian ini bertujuan untuk mengumpulkan data bahan pakan inkonvensional dari limbah pertanian dan perkebunan di Kabupaten Banyuwangi. Pakan merupakan aspek terpenting dalam pengelolaan peternakan. Ketersediaan pakan baik di musim hujan maupun musim kemarau harus tetap ada. Penelitian ini menggunakan metode purposive sampling sehingga sampel diambil di Kecamatan Kalibaru, Genteng, Purwoharjo, Songgon, Banyuwangi, Licin, Glagah dan Wongsorejo. Sampel bahan selanjutnya dianalisis proksimat untuk mengetahui kadar serat kasar (SK), protein kasar (PK), lemak kasar (LK), bahan ekstrak tanpa nitrogen (BETN) dan kadar abu. Hasil menunjukkan bahwa limbah jerami padi, jerami kedelai, nanas, rumput gajah, alang-alang, rumput lapang, kaliandra, turi dan lamtoro memiliki dominasi kandungan gizi yang bervariasi. Simpulan penelitian bahwa bahan limbah dapat diformulasikan sebagai pakan ternak inkonvensional.
\end{abstract}

Kata kunci: limbah, pertanian, perkebunan, pakan inkonvensional, Banyuwangi

\section{Abstract}

The aim of this study was to collect all the inconventional feed from agricultural and plantation byproducts in Banyuwangi. Feed is most important aspect in livestock management. Feed must sustain not only in winter but also in summer. This study was used purposive sampling method, so there were eight district ie: Kalibaru, Genteng, Purwoharjo, Songgon, Banyuwangi, Licin, Glagah and Wongsorejo. All samples were analyzed with proximat analysis to measure crude fiber, crude protein, crude lipid, non protein nitrogen and carbon level. The result showed that rice hay, soy hay, pineapple, king grass, reeds, field grass, kaliandra, turi and legume had high nutrition. This study concluded that all of agricultural and plantation byproducts could to be formulation as inconventional feed.

Key words: byproduct, agricultural, plantation, inconventional feed, Banyuwangi

\section{PENDAHULUAN}

Usaha produksi peternakan sangat tergantung dari ketersediaan bahan pakan hijauan yang baik dan kualitasnya terjamin, karena dengan hal itu berarti bahwa produktivitas peternakan dapat dinaikkan apabila pakan diberikan secara optimal untuk memenuhi kebutuhan ternak (Cheng et al.,2009).

Pakan merupakan komponen produksi dengan biaya yang terbesar. Biaya pakan dapat mencapai $60-80 \%$ dari biaya produksi. Kualitas pakan harus diperhatikan agar ternak tumbuh secara maksimal. Hijauan merupakan pakan ruminansia yang utama, sehingga penyediaan hijauan dan kualitasnya sangat menentukan produktivitas dan perkembangan ternak ruminansia. Kendala yang muncul berkaitan dengan kualitas, kuantitas dan kesinambungan dari ketersediaan pakan ternak disebabkan oleh beberapa faktor antara lain, yaitu: komponen iklim, kondisi tanah, luas lahan yang semakin 
sempit serta musim kemarau dengan suhu yang tinggi membuat tanaman pakan untuk ternak sulit didapatkan, terutama jenis rumputrumputan. Produksi limbah pertanian dan agroindustri sampai saat ini masih merupakan produk yang belum dimanfaatkan secara baik, sehingga perlu dikaji kemungkinan pemanfaatannya sebagai pakan ternak yang optimal. Limbah tanaman pertanian dapat dibedakan atas dua golongan pokok, yaitu limbah tanaman pertanian pasca panen dan limbah tanaman pertanian sisa industri pengolahan hasil pertanian, limbah tanaman pertanian pasca panen adalah bagian tanaman di atas tanah atau pucuknya yang tersisa setelah dipanen atau diambil hasil utamanya, sedangkan yang dimaksud limbah pertanian sisa industri pengolahan hasil pertanian adalah sisa dari pengolahan bermacam-macam hasil utama pertanian (Soejono, 1995).

Menurut Acker (1971) limbah tanaman pertanian atau limbah industri pengolahan hasil pertanian dapat dikelompokkan berdasarkan kandungan proteinnya menjadi 3 (tiga) kualitas yaitu kandungan protein kurang dari $10 \%$, kandungan protein $10-18 \%$ dan kandungan protein lebih dari $18 \%$ dari Bahan keringnya. Bahan - bahan pakan yang berasal dari limbah pertanian dan industri pengolahan hasil pertanian ini mengandung komposisi kimia yang sangat diperlukan sebagai langkah awal dalam menyusun ransum ternak. Ransum merupakan campuran 2 atau beberapa bahan pakan yang disusun dan dihitung (dikalkulasi) sebelumnya berdasarkan kebutuhan nutrisi dan energi yang diperlukan oleh ternak. Berdasarkan bentuknya, ransum dapat dibagi menjadi tiga jenis yaitu mash, pellet, dan crumble (Sihombing, 1984). Proses pembuatan formula ransum dengan bahan dasar limbah, wajib memperhatikan limbah yang rendah proteinnya harus diimbangi dengan limbah yang kaya protein. Demikian juga unsurunsur lainnya sehingga memperoleh ransum yang saling melengkapi.

Desa tamansari memiliki potensi pertanian yang melimpah untuk tanaman padi dan tanaman lainnya seperti cengkeh, kopi, ubi jalar, ubi kayu (Kecamatan Licin, 2014). Selain itu beberapa wilayah di Kabupaten Banyuwangi juga memiliki potensi pertanian maupun perkebunan yang besar dan merata (Dinas Pertanian, Kehutanan dan Perkebunan, 2012). Pemanfaatan limbah hasil petanian maupun perkebunan yang kurang optimal, maka perlu diketahui informasi database bahan limbah pertanian dan limbah hasil samping industri pengolahan pertanian sebagai bahan dalam penyusunan formula ransum ternak ruminansia, sehingga dapat meningkatkan produktivitas ternak.

\section{METODE PENELITIAN}

\section{Metode Sampling}

Sampel diperoleh dengan cara purposive sampling, yakni wilayah kecamatan yang memiliki produktivitas pertanian dan perkebunan minimal mencapai 1 ton. Asumsi yang digunakan dimaksudkan untuk mendapatkan limbah pertanian yang beraneka ragam dan berpotensi memiliki kandungan nutrisi pakan ternak. Kecamatan yang didapatkan, antara lain: Kalibaru, Genteng, Purwoharjo, Songgon, Banyuwangi, Licin, Glagah dan Wongsorejo. Sampel limbah pertanian dan perkebunan selanjutnya didata dan dipersiapkan sebagai sampel bahan yang diuji analisis proksimat.

\section{Analisis Proksimat}

Metode analisis proksimat yang digunakan merupakan metode (AOAC, 2005) yang sampai dengan saat ini masih digunakan di Laboratorium Makanan Ternak, Departemen Peternakan, Fakultas Kedokteran Hewan, Universitas Airlangga Surabaya. Analisis proksimat terdiri dari analisis Bahan kering (BK), kandungan air, analisis protein kasar (PK), analisis lemak kasar (LK), serat kasar (SK), analisis kadar zat anorganik atau kadar abu dan mineral kalsium $(\mathrm{Ca})$ serta fosfor $(\mathrm{P})$. Analisis proksimat biasanya dilengkapi dengan pengukuran metabolisme energi (ME), Total Digestive Nutrient (TDN) dari bahan pakan tersebut.

Contoh analisis yang dikirim biasanya dalam keadaan basah atau kering. Contoh basah/segar ditimbang terlebih dahulu untuk mengetahui berat basahnya, kemudian diimasukkan dalam 
oven $60^{\circ} \mathrm{C}$ untuk memperoleh berat Bahan keringnya selanjutnya digiling dengan saringan berdiameter $0,5-1,0 \mathrm{~mm}$. Contoh yang siap dianalisis disimpan dalam botol plastik bertutup dan diberi nomor analisis. Pengambilan contoh harus mewakili contoh yang dikirim ke laboratorium sesuai dengan petunjuk pengambilan contoh analisis (Askar et al, 1997).

\section{Analisis Data}

Data yang diperoleh disajikan secara deskriptif untuk jenis limbah pertanian dan perkebunan setiap kecamatan dan dibahas berdasarkan hasil analisis bahan.

\section{HASIL DAN PEMBAHASAN}

Hasil yang didapat dari pengujian analisis proksimat setiap bahan di masing-masing kecamatan memunculkan kadar gizi serat kasar (SK), protein kasar (PK), lemak kasar (LK), bahan ekstrak tanpa nitrogen (BETN) dan kadar abu seperti pada tabel 1 .

Wilayah Kabupaten Banyuwangi secara umum merupakan wilayah terbesar di Provinsi Jawa Timur dengan perkebunan, kehutanan yang sangat melimpah, khususnya potensi pertaniannya. Sektor pertanian merupakan sektor paling dominan bila diperhatikan berdasarkan struktur ekonomi Kabupaten Banyuwangi. Khusus dalam sektor pertanian ini, terdapat dua subsektor didalamnya yang sangat potensial, yaitu subsektor tanaman bahan makanan dan subsektor perikanan laut. Peranan subsektor tanaman bahan makanan dapat menyumbang produksi padi Jawa Timur karena Kabupaten Banyuwangi merupakan salah satu daerah lumbung padi dengan jumlah sebesar dengan 792.573 ton pada tahun 2012. Selain itu produksi jagung dan kedelai juga menjadi salah satu komoditas pertanian dari Kabupaten Banyuwangi. Pada tahun 2012 produksi jagung sebesar 141.125 ton dan produksi kedelai 53.648 ton (Dinas Pertanian, Kehutanan dan Perkebunan, 2012).

Kabupaten Banyuwangi memiliki peluang besar untuk dijadikan sebagai lahan pertanian. Berdasarkan pemanfaatan luas lahan yang digunakan oleh para petani, mulai kawasan
Timur (Kecamatan Wongsorejo) kemudian Selatan (Kecamatan Purwoharjo) ke arah Utara (Kecamatan Licin dan Kecamatan Songgon) yang melebar ke arah Barat (Kecamatan Genteng) merupakan daerah potensi tanaman bahan makanan, terutama tanaman padi yang sebagain besar dari kawasan tersebut pola tanam dalam satu tahunnya bisa dilakukan hingga tiga kali. Selain sektor pertanian, Kabupaten Banyuwangi juga memiliki potensi yang besar melalui sektor perkebunan yang sebagian besar di wilayah Kecamatan Kalibaru, Kecamatan Licin, Kecamatan Glagah dan terbagi pada beberapa kawasan. Kawasan peruntukan perkebunan negara luas kurang lebih 30.976 ha (tebu, kopi, karet, dan kakao). Perkebunan swasta luas kurang lebih 18.024 ha (kopi, coklat, kartet, cengkeh, abaca, kapuk randu, vanili). Perkebunan Rakyat luas kurang lebih 31.964 ha (kelapa buah, kelapa deres, kopi, coklat, cengkeh, vanili, kapas, kapuk randu, nilam, jarak, tembakau). Produksi kelapa tahun 2012 sebesar 155.966 ton (Dinas Pertanian, Kehutanan dan Perkebunan, 2012).

\section{Kadar Gizi dalam Bahan Limbah Pertanian}

Strategi pemanfaatan sumber pakan lokal sangat dibutuhkan dalam pengembangan ternak unggul di Banyuwangi karena pakan merupakan faktor terpenting dalam usaha peternakan. Bahan pakan konvensional sering menjadi tidak ekonomis apalagi dilakukan pada peternakan skala rakyat dengan kepemilikan ternak yang sedikit. Langkah yang tepat untuk pengembangan ternak di Banyuwangi yaitu melalui optimalisasi sumber pakan lokal yang bersifat inkonvensional.

Pakan lokal adalah setiap bahan baku yang merupakan sumberdaya lokal yang berpotensi sebagai pakan secara efisien baik sebagai suplemen, komponen konsentrat atau pakan dasar. Pakan lokal tersebut dapat berupa hasil sisa tanaman (crop residues), hasil ikutan atau samping atau limbah tanaman (crop byproducts) dan hasil ikutan atau samping atau limbah agroindustri (agroindustry byproducts) (Wiryawan, 2012). 
Tabel 1. Analisis proksimat limbah pertanian dan perkebunan di Banyuwangi

\begin{tabular}{|c|c|c|c|c|c|c|}
\hline Kecamatan & Bahan & SK & PK & LK & BETN & Abu \\
\hline \multirow{7}{*}{ Kalibaru } & Ubi kayu & 4,90 & 2,90 & 0,70 & 89,20 & 2,30 \\
\hline & Daun ubi kayu & 14,93 & 8,39 & 5,58 & 45,86 & 14,75 \\
\hline & Ubi jalar & 10,83 & 5,37 & 5,15 & 65,20 & 5,37 \\
\hline & Jerami ubi jalar & 16,20 & 19,20 & 2,60 & 45,90 & 16,10 \\
\hline & Ketela pohon & 13,93 & 2,93 & 2,87 & 62,69 & 5,93 \\
\hline & Kulit ubi jalar & 12,20 & 6,77 & 5,84 & 46,52 & 12,41 \\
\hline & Kulit ubi kayu & 16,77 & 7,59 & 3,70 & 56,33 & 6,79 \\
\hline \multirow{2}{*}{ Genteng } & Biji kapas & 34,86 & 21,91 & 10,26 & 16,50 & 5,04 \\
\hline & Daun randu & 10,97 & 9,83 & 3,12 & 15,98 & 5,26 \\
\hline \multirow{5}{*}{ Purwoharjo } & Daun mahoni & 10,84 & 6,77 & 5,24 & 29,25 & 5,24 \\
\hline & Daun sono & 7,18 & 7,74 & 1,61 & 7,06 & 3,27 \\
\hline & Daun residi & 1,32 & 6,49 & 3,83 & 3,86 & 2,04 \\
\hline & Daun jati & 31,02 & 5,05 & 0,6 & 37,56 & 20,74 \\
\hline & Jerami tomat & 20,67 & 7,23 & 5,15 & 25,03 & 29,24 \\
\hline \multirow{3}{*}{ Songgon } & Jerami padi & 31,38 & 5,61 & 1,72 & 29,14 & 18,44 \\
\hline & Dedak kasar & 31,54 & 5,62 & 3,42 & 31,43 & 18,53 \\
\hline & Dedak halus & 27,50 & 9,23 & 1,83 & 39,77 & 16,12 \\
\hline \multirow{9}{*}{ Banyuwangi } & Limbah ikan & 5,32 & 59,00 & 10,50 & 0,12 & 10,43 \\
\hline & Tepung ikan & 3,16 & 53,51 & 4,44 & 7,37 & 16,54 \\
\hline & Kepala udang & 10,82 & 43,48 & 0,29 & 19,03 & 23,38 \\
\hline & Daun alpokat & 28,14 & 4,72 & 6,13 & 38,16 & 13,24 \\
\hline & Kulit alpokat & 29,01 & 8,22 & 3,82 & 37,81 & 7,35 \\
\hline & Daun nangka & 27,20 & 6,52 & 4,06 & 38,83 & 11,57 \\
\hline & Daun pring & 29,46 & 4,16 & 0,85 & 39,63 & 17,57 \\
\hline & Daun jambu biji & 21,60 & 4,18 & 5,69 & 51,20 & 6,96 \\
\hline & Kulit nangka & 28,86 & 6,34 & 4,82 & 21,33 & 22,88 \\
\hline \multirow{12}{*}{ Licin } & Limbah nanas & 16,29 & 6,25 & 5,70 & 41,42 & 5,86 \\
\hline & Rumput odot & 10,38 & 3,41 & 0,48 & 12,19 & 6,29 \\
\hline & Rumput alang-alang & 18,98 & 6,51 & 0,69 & 29,87 & 9,13 \\
\hline & Kaliandra & 19,80 & 25,00 & 2,48 & 47,20 & 5,90 \\
\hline & Lamtoro & 20,10 & 31,74 & 8,76 & 30,48 & 5,22 \\
\hline & Turi & 33,13 & 8,67 & 5,33 & 25,65 & 15,33 \\
\hline & Cengkeh & 23,44 & 8,60 & 12,11 & 23,73 & 22,81 \\
\hline & Daun pepaya & 24,51 & 8,06 & 6,77 & 43,68 & 7,25 \\
\hline & Kulit nanas & 29,25 & 7,92 & 6,68 & 31,53 & 7,25 \\
\hline & Daun nanas & 34,58 & 7,76 & 3,82 & 26,36 & 15,09 \\
\hline & Kulit pepaya & 13,89 & 7,17 & 5,30 & 39,31 & 9,08 \\
\hline & Rumput lapang & 30,11 & 3,05 & 3,39 & 44,49 & 7,53 \\
\hline \multirow{7}{*}{ Glagah } & Bungkil kelapa & 15,38 & 18,58 & 12,55 & 37,26 & 6,36 \\
\hline & Kulit buah coklat & 40,09 & 7,15 & 2,60 & 29,29 & 9,73 \\
\hline & Kulit kopi & 32,15 & 4,71 & 4,94 & 28,08 & 14,71 \\
\hline & Batang pisang & 1,72 & 1,64 & 2,15 & 1,42 & 1,27 \\
\hline & Daun pisang & 38,23 & 7,77 & 5,18 & 24,19 & 14,14 \\
\hline & Kulit kelapa & 43,82 & 3,82 & 5,76 & 30,31 & 6,25 \\
\hline & Daun kelapa & 34,57 & 4,64 & 3,88 & 38,79 & 8,69 \\
\hline \multirow{7}{*}{ Wongsorejo } & Jerami jagung & 30,53 & 4,77 & 1,06 & 55,82 & 8,42 \\
\hline & Jagung & 34,72 & 10,78 & 2,18 & 48,15 & 2,78 \\
\hline & Klobot jagung & 28,08 & 3,78 & 4,43 & 26,34 & 5,86 \\
\hline & Ampas tahu & 0,93 & 2,8 & 0,31 & 9,05 & 0,35 \\
\hline & Bekatul & 5,75 & 10,77 & 10.97 & 57.41 & 3,27 \\
\hline & Tongkol jagung & 22,97 & 6,23 & 2,84 & 43,11 & 2,74 \\
\hline & Bungkil jagung & 34,05 & 6,70 & 5,76 & 31,45 & 10,22 \\
\hline
\end{tabular}

(Sumber: UPVAP, 2016) 
Pertanian di Kabupaten Banyuwangi merupakan sektor yang memberikan kontribusi cukup besar bagi sumber pendapatan daerah. Sektor ini terbagi menjadi subsektor tanaman pangan, tanaman hortikultura, dan tanaman perkebunan yang tentunya menghasilkan potensi biomasa yang cukup besar sebagai sumber pakan lokal bagi pengembangan ternak ruminansia di kabupaten Banyuwangi.

Kualitas nutrisi bahan pakan ternak merupakan faktor utama dalam menentukan kebijakan dalam pemilihan dan penggunaan bahan makanan tersebut sebagai sumber zat makanan untuk memenuhi kebutuhan hidup pokok dan produksi. Kualitas nutrisi bahan pakan terdiri atas komposisi nilai gizi, serat dan energi serta aplikasinya pada nilai palatabilitas dan daya cerna. Penentuan komposisi nilai gizi secara garis besarnya dapat dilakukan dengan analisa proksimat, dimana dapat ditentukan kandungan air, abu, protein kasar, lemak kasar, serat kasar dan bahan ekstrak tanpa nitrogen (BETN). Dengan analisa proksimat komponenkomponen fraksi serat tidak dapat tergambarkan secara terperinci berdasarkan manfaatnya dan kecernaan pada ternak (Wiryawan, 2012).

Untuk mendapatkan hasil analisa yang lebih akurat dan menggambarkan kondisi kandungan nilai gizi bahan makanan ternak yang sebenarnya, faktor-faktor yang harus diperhatikan, yaitu : pengambilan sample (metode sampling), penggunaan alat dan bahan kimia yang sesuai, metode analisa dengan tingkat ketelitian yang tinggi serta satuan hasil analisa. Berdasarkan hasil analisa kimianya selanjutnya dapat ditentukan klasifikasi bahan makanan sebagai sumber protein, energi atau mineral dan vitamin. Hal ini sangat diperlukan dalam membuat formula-formula ransum yang sesuai dengan standar kebutuhan ternak selain juga tetap mempertimbangkan harga ransum.

Bahan makanan ternak akan selalu terdiri dari zat-zat makanan yang terutama diperlukan oleh ternak dan harus kita sediakan. Zat makanan utama antara lain protein, lemak dan karbohidrat perlu diketahui sebelum menyusun ransum. Untuk itu perlu dilakukan analisa laboratorium guna mengetahuinya. Henneberg dan Stohmann dari Weende Experiment Station di Jerman membagi pakan menjadi 6 (enam) fraksi, yaitu : kadar air, abu, protein, lemak kasar, serat kasar dan bahan ekstrak tanpa nitrogen (BETN) (Wiryawan, 2012).

\section{Analisa Air}

Analisis kadar air bahan menggunakan oven dengan temperatur sedikit diatas temperatur didih air yaitu $105^{\circ} \mathrm{C}$. Sampel dimasukan ke dalam oven beberapa waktu sehingga tercapai berat tetap. Kadar air adalah selisih berat awal dan akhir dalam satuan persen (Wiryawan, 2012). Umumnya pakan yang telah mengalami pengeringan matahari atau oven $70^{\circ} \mathrm{C}$ masih mengandung kadar air. Dari analisis ini akan diperoleh kadar bahan kering (bahan yang sudah bebas air dan uap air) dengan cara 100\% dikurangi dengan kadar air.

\section{Analisa Abu}

Abu adalah bagian dari sisa pembakaran dalam tanur dengan temperatur $400-600^{\circ} \mathrm{C}$ yang terdiri atas zat-zat anorganik atau mineral. Beberapa bahan limbah hasil pertanian yang didapatkan di wilayah Kabupaten Banyuwangi yang memiliki angka tertinggi dalam prosentase analisa abu adalah jerami padi dengan 19,9\% dan jerami kacang tanah dengan 18,6\% .

\section{Analisa Protein Kasar}

Pengertian protein kasar adalah semua zat yang mengandung nitrogen. Diketahui bahwa dalam protein rata-rata mengandung nitrogen 10\% (kisaran 13- 19\%) (Wiryawan, 2012). Kandungan protein kasar (PK) pada bungkil kacang tanah dan sekam adalah 35,7\%, dan untuk bungkil kedelai mengandung $47 \%$. Kualitas protein bungkil kacang tanah adalah baik dan hampir sama dengan bungkil kedelai. Tetapi bungkil kacang tanah biasanya mengandung lisin yang lebih rendah daripada bungkil kedelai. Bungkil kacang tanah mengandung kalsium $(\mathrm{Ca})$ yang rendah dan kandungan phospor $(\mathrm{P})$ setengah dari kandungan bungkil biji kapas.

\section{Analisa Lemak Kasar}

Kadar lemak dalam analisis proksimat ditentukan dengan mengekstraksikan bahan pakan dalam pelarut organik. Zat lemak terdiri dari karbon, oksigen dan hidrogen. Lemak yang 
didapatkan dari analisis lemak ini bukan lemak murni akan tetapi campuran dari berbagai zat yang terdiri dari klorofil, xantofil, karoten dan lain-lain (Murtidjo, 1987). Kemudian untuk penetapan kandungan lemak dilakukan dengan larutan N-heksan sebagai pelarut. Fungsi dari Nheksan adalah untuk mengekstraksi lemak atau untuk melarutkan lemak, sehingga merubah warna dari kuning menjadi jernih (Mahmudi, 1997). Kandungan lemak kasar yang dimiliki bungkil kacang tanah sebesar 11,17\%. Kecamatan Wongsorejo dan Kalipuro merupakan daerah dengan produksi kacang tanah yang terbesar dari wilayah Kabupaten Banyuwangi.

\section{Analisa Serat Kasar}

Serat kasar mempunyai pengertian sebagai fraksi dari karbohidrat yang tidak larut dalam basa dan asam encer setelah pendidihan masingmasing 30 menit. Termasuk dalam komponen serat kasar ini adalah campuran hemisellulosa, sellulosa dan lignin yang tidak larut. Dalam analisa ini diperoleh fraksi lignin, sellulosa dan hemisellulosa yang justru perlu diketahui komposisinya khusus untuk hijauan makanan ternak atau umumnya pakan berserat (Wiryawan, 2012).

Kandungan serat kasar yang tinggi dari komoditas limbah pertanian di wilayah Kabupaten Banyuwangi adalah daun ubi kayu sebesar $24,1 \%$. Selain serat kasar tinggi, asam amino daun ubi kayu ternyata hampir sama dengan bungkil kedelai walaupun jumlahnya berbeda. Daun ubi kayu defisien asam amino esensial yang mengandung sulfur yaitu methionin dan sistin.

\section{Bahan Ekstrak tanpa Nitrogen (BETN)}

Untuk memperoleh BETN adalah dengan cara perhitungan : 100\% - (Air + Abu + Protein Kasar + Lemak Kasar + Serat Kasar)\%. Dalam fraksi ini termasuk karbohidrat yang umumnya mudah tercerna antara lain pati dan gula (Wiryawan, 2012). Bahan hasil pertanian ampas nanas berupa kulit dan daun merupakan limbah yang mengandung BETN dengan 63,9\%. Ampas nanas masih mengandung kadar gula yang tinggi dan serat kasarnya juga cukup tinggi tetapi proteinnnya rendah.

\section{Potensi Jerami Padi}

Jerami padi merupakan limbah pertanian terbesar di Indonesia. Jumlah jerami padi yang dapat dimanfaatkan secara nasional pada tahun 2001 adalah 92 juta ton (Ditjen Bina Produksi Peternakan Deptan, 2004). Menurut Van Soest (1982) pemanfaatan jerami padi sebagai pakan ternak ruminansia sudah umum dilakukan dan berbagai upaya telah dilakukan untuk meningkatkan manfaat penggunaannya yaitu melalui amoniasi dan penambahan enzim pada jerami padi yang sudah diamoniasi.

Sejauh ini, pemanfaatan jerami padi sebagai pakan ternak baru mencapai 31-39\%, sedangkan yang dibakar atau dimanfaatkan sebagai pupuk 36-62 \%, dan sekitar 7-16 \% digunakan untuk keperluan industri (safan, 2008). Fermentasi jerami (mustard straw) dengan fungi G. lucidum pada suhu $35^{\circ} \mathrm{C}$ selama 21 hari menghasilkan nilai kecernaan in vitro dan delignifikasi yang maksimal (Misra et al. 2007).

Limbah tanaman padi, baik limbah lapangan maupun limbah pengolahan memberikan kontribusi yang paling besar dalam penyediaan bahan baku pakan. Estimasi limbah yang dikeluarkan dari penanaman padi dengan produksi gabah pada tahun 2004 sebesar 54.088.468 ton adalah 2,2 juta ton beras pecah, ,4 juta ton dedak, 8,7 juta ton sekam dan 54 juta ton jerami (Murni, 2008).

Jerami padi merupakan sisa dari pemanenan padi yang terdiri dari batang dan daun. Kualitas jerami padi sangat bervariasi, kandungan protein kasar berkisar antara 2-7\%, ADF 41-56\%, TDN (Total Digestible Nutrient) 43-54\%, abu $\pm 17 \%$, $\mathrm{Ca} 0,2-0,7 \%$ dan $\mathrm{P} 0,07-0,16 \%$. Jerami padi yang diberikan secara ad libitum tidak dapat memenuhi kebutuhan ternak karena hanya mempunyai kecernaan 35 - $37 \%$ dengan kandungan protein kasar 3 - $4 \%$ padahal untuk hidup pokok ternak ruminansia membutuhkan kecemaan 50 - $55 \%$ dengan protein kasar $8 \%$ (Soejono dan Widyantoro, 1987).

Pakan disebut sebagai faktor pembatas yang paling penting dalam suatu peternakan terutama jika dilihat dari sudut pandang pembiayaan yang berkisar antara 60-70 \% dari biaya produksi. Ternak ruminansia terutarna sapi, kerbau, 
kambing dan domba pakan utamanya adalah hijauan sedang tambahannya berupa konsentrat. Tetapi pada musim kemarau produksi hijauan kurang dan untuk menanggulangi masalah tersebut maka dimanfaatkan limbah pertanian berupa jerami padi (Suharno dan Nazaruddin,1994). Produksi limbah pertanian mempunyai potensi yang cukup besar untuk memenuhi kebutuhan ternak akan pakan hijauan (Soejono dan Widyantoro, 1987). Hal ini didukung oleh Lebdosoekojo (1982), yang menyatakan bahwa jerami padi sebagai sisa hasil pertanian merupakan sumber utama bagi pakan ternak ruminansia, di beberapa daerah terutama pada musim kemarau yang saat itu persediaan pakan sangat terbatas.

Hambatan pemanfaatan jerami padi dalam manajemen pakan ternak ruminansia adalah rendahnya nilai nutrisi jerami bila dibandingkan dengan hijauan pakan. Hal ini disebabkan karena kandungan protein kasar, kecernaan dan kandungan mineral rendah sehingga konsumsi bahan keringnya terbatas (Soejono dan Widyantoro, 1987; Sastradipradja, 1981). Jerami padi mengandung zat-zat makanan yang rendah terutama protein kasar (3-5\%) tetapi kandungan serat kasarnya tinggi $(31,5-46,5 \%)$ sehingga kemampuan ternak untuk mengkonsumsi bahan kering hanya sekitar $2 \%$ dari bobot badan dan daya cerna berkisar antara. 35-40\% (Rangkuti,1984). Hal ini juga didukung oleh Sitorus (1986), yang menyatakan bahwa disamping kandungan proteinnya rendah, kandungan $\mathrm{Ca}$ dan $\mathrm{P}$ pada jerami padi juga rendah yaitu Ca sekitar 0,15\% dan P sekitar 0,10 $\%$ dari bahan kering, sehingga harus disertai dengan suplemen yang mengandung protein $(\mathrm{N})$, energi dan mineral murni misalnya : molases (tetes). Sedangkan Ffoulkes dan Bamualim (1989) menyatakan bahwa, jerami padi mengandung bahan kering 33-95\% dan berbeda dengan hijauan pakan lainnya karena tingginya kandungan silica dan rendahnya kandungan kalsium dan fosfor.

Pemanfaatan jerami padi sebagai pakan merupakan persoalan selain gizinya rendah, jerami padi sebagian besar dibakar atau dikembalikan ke tanah sebagai kompos dan digunakan. untuk keperluan industri. Nilai gizinya yang rendah merupakan faktor pembatas yang disebabkan karena Jerami padi berasal dari tanaman tua yang telah dipetik hasil utamanya sehingga mempunyai ikatan selulosa dan hemiselulosa dengan lignin yang kuat (Harahap, 1987).

Pakan tambahan merupakan bahan yang mengandung jasad renik (mikroba) yang dapat menguraikan jerami padi sehingga nutrisinya mudah untuk diserap dan memacu laju pertambahan berat badan, misaInya starbio, bioplus dan bossdext (Sarwono, 2003). Pemanfaatan jerami padi secara langsung sebagai pakan tunggal tidak dapat memenuhi kebutuhan nutrisi pada ternak dan dapat menurunkan produktivitas ternak, oleh karena pasokan protein dibutuhkan oleh mikroba rumen untuk pertumbuhan dan meningkatkan populasi optimum untuk proses degradasi serat bahan pakan dalam rumen. Untuk mengatasi hal itu perlu dilakukan pengolahan yang sesuai sehingga bahan pakan ligniselulosik memiliki kualitas yang cukup sebagai pakan ternak ruminansia (Yunilas, 2009).

\section{Potensi Kulit Gabah atau Sekam Padi}

Kulit gabah adalah lapisan keras yang meliputi kariopsis, terdiri dari dua belahan yang disebut lemma dan palea yang saling bertautan. Sekitar $17 \%$ dari berat total gabah adalah kulit gabah atau sekam. Kulit gabah dapat digunakan untuk berbagai keperluan, antara lain bahan energi alternatif, bahan baku industry kimia dan bahan baku industry bangunan dan bahan pakan ternak. Kulit gabah termasuk bahan pakan berkualitas rendah. Menurut Murni (2008) komposisi kimia kulit gabah adalah bahan kering $92 \%$, protein kasar 3,0\%, abu 19\%, serat kasar $39,6 \%$, dinding sel 76,0\%, selulosa $30,0 \%$, lignin $15 \%$ dan ADF $66,0 \%$. Kulit gabah biasanya digiling terlebih dahulu sebelum dicampurkan dengan bahan pakan lain yang lebih palatabel.

\section{Potensi Kulit Buah Coklat}

Kulit buah kakao dimanfaatkan sebagai sebagai pupuk, pembuatan gas bio atau sebagai bahan pembuat pektin. Selain itu pulp dari limbah fermentasi biji berguna dalam pembuatan alcohol (Siregar et al. 1992). Buah coklat terbagi 
atas kulit buah, pulp, placenta, dan biji. Kulit buah adalah kulit bagian terluar yang menyelubungi buah kakao dengan tekstur kasar, tebal, dan agak keras.

Menurut Smith dan Adegbola (1982) bahwa kulit buah kakao merupakan hasil dari proses pengolahan buah kakao yang telah dipisahkan dari buahnya dan merupakan salah satu limbah yang sangat potensial untuk dijadikan bahan makanan ternak ruminansia. Kulit buah kakao dapat menjadi salah satu bahan dalam sistem pakan ternak. Kulit buah kakao merupakan bahan makanan ternak yang berserat tinggi dan mengandung bahan lignoselulotik (Roesmanto, 1991). Bahan yang demikan umumnya sudah mengalami proses lignifikasi lanjut dan selulosanya sudak berbentuk kristal dan tidak lagi berbentuk amorf (Jackson, 1978).

Selanjutnya dikatakan bahwa buah kakao yang masak mempunyai kulit buah yang tebal dan di dalam setiap buah terdapat 30-50 biji, tergantung pada varietasnya. Bijinya dikelilingi oleh pulp yang berlendir seperti getah. Penggunaan kulit kakao untuk ternak sapi bisa 30-40\% dari kebutuhan pakan, dengan demikian pemanfaatan kulit buah kakao dapat mengantisipasi masalah kekurangan pakan ternak serta menghemat tenaga kerja dalam penyediaan pakan hijauan (Anas et al., 2011).

\section{Potensi Kulit Kopi}

Kopi termasuk tanaman yang menghasilkan limbah hasil sampingan yang cukup besar dari hasil pengolahan. Limbah sampinhan tersebut berupa kulit kopi yang jumlahnya berkisar antara 50 - 60 persen dari hasil panen. Bila hasil panen sebanyak $1000 \mathrm{~kg}$ kopi segar berkulit, maka yang menjadi biji kopi sekitar 400-500 kg dan sisanya adalah hasil sampingan berupa kulit kopi. Limbah kulit kopi belum dimanfaatkan petani secara optimal. Padahal kulit kopi bisa dimanfaatkan sebagai bahan dasar pembuatan pupuk kompos (Puslitkoka, 2005) dan bisa digunakan sebagai pakan karena kulit kopi mempunyai kecernaan protein sebesar $65 \%$ dan 51,4\% untuk kulit biji (Azmi dan Gunawan, 2006).

Kulit kopi cukup potensial untuk digunakan sebagai bahan pakan ternak ruminansia baik itu ruminansia kecil maupun ruminansia besar. Kandungan nutrisi kulit kopi non fermentasi seperti protein kasar sebesar 8,49\%, Hasil analisa proksimat relatif sebanding dengan kandungan zat nutrisi rumput. Kulit kopi diberikan langsung dalam bentuk basah, kadar air yang cukup tinggi sehingga mudah rusak dan kurang disukai ternak. Namun selain itu tingginya kandungan serat kasar dan adanya kandungan tanin, cafein dan lignin pada kulit kopi non fermentasi yang dapat mengganggu pencernaan ternak jika diberikan dalam jumlah banyak. Salah satu cara untuk meminimalkan faktor pembatas tersebut, kulit kopi diolah terlebih dahulu sebelum diberikan kepada ternak. Salah satu proses pengolahan yang dapat dilakukan adalah teknologi fermentasi (Azmi dan Gunawan, 2006).

\section{Formulasi Ransum Ternak}

Keberhasilan program pengembangan dalam produktivitas suatu peternakan bukan hanya ditentukan oleh program kesehatan dan pemasaran saja, akan tetapi program nutrisi dengan menekan biaya pakan ternak yang masih memenuhi standar mutu pemenuhan nutrisi ternak merupakan salah satu faktor terpenting. Tujuan utama pemberian pakan pada ternak adalah menyediakan ransum yang ekonomis namun dapat memenuhi kebutuhan hidup pokok, kebuntingan, dan produksi susu induk, serta kebutuhan untuk pertumbuhan bagi ternak muda.

Pemberian pakan pada ternak harus memperhatikan besaran dan jumlah prosentase kandungan nutrisi yang akan diberikan. Beberapa kandungan nutrisi yang perlu dipenuhi adalah energi, protein, karbohidrat, mineral, dan vitamin. Penyusunan ransum yang tepat dengan menyesuaikan kandungan dari bahan limbah pertanian yang didapatkan melalui metode analisa proksimat dengan standard kebutuhan nutrisi dari ternak.

Beberapa standard kebutuhan nutrisi untuk sapi potong adalah 1) sapi potong penggemukan membutuhkan lemak kasar sebesar 7\%, abu sebesar $12 \%$, protein kasar 13\%. 2) sapi potong induk membutuhkan protein kasar sebesar $14 \%$, abu sebesar 12\%, lemak kasar sebesar 6\%, sedangkan 3) sapi potong pejantan 
membutuhkan abu sebesar $12 \%$, protein kasar sebesar $12 \%$, lemak kasar sebesar $6 \%$ (BSN, 2009). Berdasarkan standard tersebut dapat dilakukan formulasi ransum dengan biaya pakan yang rendah dengan memanfaatkan bahan limbah pertanian lokal sebagai pakan. Formulasi ransum sapi potong yang ideal di wilayah Kabupaten Banyuwangi dengan menggunakan jerami padi sebesar 30\%, jerami kedelai $60 \%$ dan daun ubi kayu $10 \%$ dari total pakan ternak. Kandungan total ransum pakan sapi potong tersebut yaitu abu sebesar $10.74 \%$, protein kasar sebesar $18.76 \%$, lemak kasar sebesar $2.41 \%$, serat kasar sebesar $22.73 \%$, BETN sebesar $45.58 \%$, ME sebesar $2530.07 \mathrm{kkal} / \mathrm{kg}$.

Standard kebutuhan nutrisi untuk sapi perah adalah 1) sapi perah dara membutuhkan lemak kasar sebesar $7 \%$, abu sebesar $10 \%$, protein kasar $15 \%$. 2) sapi perah laktasi membutuhkan protein kasar sebesar $16 \%$, abu sebesar $10 \%$, lemak kasar sebesar 7\%, sedangkan 3) sapi perah kering membutuhkan abu sebesar $10 \%$, protein kasar sebesar 14\%, lemak kasar sebesar $7 \%$ (BSN, 2009). Berdasarkan standard tersebut dapat dilakukan formulasi ransum dengan biaya pakan yang rendah dengan memanfaatkan bahan limbah pertanian lokal sebagai pakan. Formulasi ransum sapi potong yang ideal di wilayah Kabupaten Banyuwangi dengan menggunakan jerami padi sebesar 20\%, jerami kedelai $40 \%$, daun ubi kayu 20\% dan ampas tahu 20\% dari total pakan ternak. Kandungan total ransum pakan sapi potong tersebut yaitu abu sebesar 9.56\%, protein kasar sebesar $16.51 \%$, lemak kasar sebesar 2.29\%, serat kasar sebesar $18.16 \%$, BETN sebesar 52.20\%, ME sebesar 2679.00 $\mathrm{kkal} / \mathrm{kg}$.

Standard kebutuhan nutrisi untuk ternak domba dan kambing adalah 1) domba/kambing tumbuh membutuhkan protein kasar 14-19\%. 2) domba dan kambing penggemukan membutuhkan protein kasar sebesar 16\% (Cakra, 2002). Berdasarkan standar tersebut dapat dilakukan formulasi ransum dengan biaya pakan yang rendah dengan memanfaatkan bahan limbah pertanian lokal sebagai pakan. Formulasi ransum domba dan kambing yang ideal di wilayah Kabupaten Banyuwangi dengan menggunakan jerami kedelai $40 \%$, daun ubi kayu 20\%, dedak halus 20\% dan ampas tahu $20 \%$ dari total pakan ternak. Kandungan total ransum pakan domba dan kambing tersebut yaitu abu sebesar $8.03 \%$, protein kasar sebesar $17.57 \%$, lemak kasar sebesar $2.95 \%$, serat kasar sebesar $15.57 \%$, BETN sebesar $44.12 \%$, ME sebesar $2458.28 \mathrm{kkal} / \mathrm{kg}$.

\section{KESIMPULAN}

1. Limbah pertanian di Kabupaten Banyuwangi, seperti limbah jerami padi, jerami kedelai, nanas, rumput gajah, alangalang, rumput lapang, kaliandra, turi dan lamtoro memiliki dominasi kandungan gizi yang bervariasi dan dapat diformulasikan sebagai pakan ternak inkonvensional;

2. Formulasi pakan yang ideal untuk beberapa ternak di Kabupaten Banyuwangi, antara lain:

a. Ternak sapi potong terdiri dari jerami padi $30 \%$, jerami kedelai $60 \%$ dan daun ubi kayu $10 \%$;

b. Ternak sapi perah terdiri dari jerami padi $20 \%$, jerami kedelai $40 \%$, daun ubi kayu $20 \%$, dan ampas tahu $20 \%$;

c. Ternak kambing dan domba terdiri dari jerami kedelai $40 \%$, daun ubi kayu $20 \%$, dedak halus $20 \%$ dan ampas tahu $20 \%$.

\section{UCAPAN TERIMA KASIH}

Peneliti mengucapkan terima kasih kepada Badan Perencanaan Pembangunan Daerah (BAPEDA) Kabupaten Banyuwangi atas dana hibah penelitian, Dinas Peternakan Kabupaten Banyuwangi atas dukungan izin penelitian dan Lembaga Penelitian dan Inovasi Universitas Airlangga atas bimbingan luaran penelitian.

\section{DAFTAR PUSTAKA}

AOAC - Assosiation of Official Analytical Chemist. 2005. Official Methods of Analysis. $15^{\text {th }}$ Ed. Assosiation of Official Analytical Chemist, Washington DC. 
Acker, D. 1971. Animal Science and Industry. Prentice Hall, Inc. Englewood Cliff. New Jersey.

Anas, S., A. Zubair, D. Rohmadi. 2011. Study Of Gift Of Cocoa Husk Fermented Feed On Bali Cow Growth. Badan Pengkajian Teknologi Pertanian (BPTP). Gorontalo.

Askar, S., N. Marlina. 1997 . Komposisi kimia beberapa hijauan pakan. Bulletin Teknik Pertanian. 2(1):7-11.

Azmi, Gunawan. 2000. Hasil-hasil Penelitian Sistem Integrasi Ternak-Tanaman. Prosiding Lokakarya Hasil Pengkajian Teknologi Pertanian, Balai Besar Pengkajian ddan Pengembangan Teknologi Pertanian, Balitbang Pertanian bekerja sama dengan Universitas Bengkulu. Halaman 91-95.

Badan Standardisasi Nasional (BSN). 2009. Pakan Konsentrat : Sapi Perah. Jakarta.

Badan Standardisasi Nasional (BSN). 2009. Pakan Konsentrat Bagian 2 : Sapi Potong. Jakarta.

Cakra, O., Suwena, Sukmawati. 2002. Konsumsi Dan Koefisien Cerna Nutrien Pada Kambing Peranakan Etawa (Pe) Yang Diberi Pakan Konsentrat Ditambah Soda Kue (Sodium Bikarbonat). Jurusan Nutrisi Dan Makanan Ternak, Universitas Udayana, Denpasar.

Cheng, C.Y. 2009. A Study on the Leadership Behavior,Safety Culture, and Safety Performance of the Healthcare Industry World Academy of Science, Engineering and Technology. 53.

Dinas Pertanian, Kehutanan dan Perkebunan, 2012. Kabupaten Banyuwangi.

Foulkes, D., A. Bamualim. 1989. Improving The Nutrition Level of Drought Animal Using Animal Available Feeds. In Drought
Animals in Rural Develaopment. ACIAR Proc.

Harahap, N. 1987. Petunjuk Teknik Penggunaan Limbah Pertanian dan Teknologi Pengolahannya Untuk Pakan Rurninansia. Proceeding Bioconversion Project Second Workshop on Crop Residues for Feed and Other Purposes, Grati.

Jackson, M.G. 1978. Rice Straw as Livestock Feed. World Animal Review, Food and Agriculture Organization of The United Nation, Rome.

Kecamatan Licin. 2014. Profil Desa Taman Sari. Banyuwangi : Kecamatan Licin.

Mahmudi, M. 1997. Penurunan Kadar Limbah Sintesis Asam Phospat Menggunakan Cara Ekstraksi Cair-Cair dengan Solven Campuran Isopropanol dan nHeksane. Semarang: Universitas Diponegoro.

Misra, A.K., A.S. Mishra, M.K. Tripathi, R. Prasad, S. Vaithiyyanathaan, R.C. Yakhmola. 2007. Optimization of Solid State Fermentation of Mustard (Brassisca Campestris) Straw for Production of Animal Feed by White Rot Fungi (Gonoderma lucidum). Asian-Aus J Anim Sci 20.

Murni, R., Suparjo, Akmal, B.L. Ginting. 2008. Buku Ajar Teknologi Pemanfaatan Limbah untuk Pakan. Laboratorium Makanan Ternak. Fakultas Peternakan universitas Jambi.

Murtidjo. 1987. Pedoman Beternak Ayam Broiler. Yogyakarta: Kanisius.

Lebdosoekojo, S. 1982. Pemanfaatan Limbah Pertanian untuk Menunjang Kebutuhan Pakan Ruminansia. Perternuan Ilmiah Ruminansia Besar Deptan, Bogor.

Puslitkoka. 2005. Panduan Lengkap Budidaya Kakao. Agromedia Pustaka, Jakarta. 
Rangkuti, M. 1984. Meningkatkan Pemakaian Jerami Padi sebagai Pakan Ternak Ruminansia dengan Suplementasi. Proceeding Bioconversion Project Second Workshop on Cropresiduest for Feed and Other Purposes, Granti.afan. 2008. Produksi Enzim Selulase oleh Aspergillus niger dengan Substrat Jerami dalam Solid State Fermentation. Wordpress.com. Diakses pada Kamis,13/09/12 pukul 22:50.

Roesmanto, J. 1991. Kakao Kajian Sosial Ekonomi. Aditya Media, Yogyakarta.

Sarwono, B. 2003. Penggemukan Sapi Potong secara Cepat. Penebar Swadaya. Jakarta.

Sastradipradja, D. 1981. Feeding Stuffs from the Residues of Agricultural Industry. Proceeding Bioconversion Project Second Worksho on Crop Residues for $\mathrm{p}$ Feed and Other Purposes, Grati.

Sihombing, D.T.H. 1984. Ilmu Ternak Babi. Gadjah Mada University Press. Yogyakarta.

Siregar, S. B. 1994. Ransum Ternak Ruminansia. Penebar swadaya.

Sitorus, S.S. 1986. Pemberian Suplementasi Daun Lamtoro Pada Kambing Yang Mendapat Jerami Padi Sebagai Ransurn Pokok. Proceeding Bioconversion Project Second Workshop on Crop Residues for Feed and Other Purposes, Grati.
Smith, D.H., A.A. Adegbola. 1982. Studies of feeing value of agroindustrial by product and feeding value of cacao pods for cattle. Tropical Animal Production, 7 : 290-295.

Soejono. 1995. Transportasi dan Lingkungan. Yogyakarta.

Soejono, M.R. Utomo, Widyantoro. 1987. Peningkatan Nilai Nutrisi Jerami Padi dengan Berbagai Perlakuan. Proceeding Bioconversion Project Second Workshop on Crop Residues for Feed and Other Purposes, Grati.

Suhamo, B., Nazaruddin. 1994. Ternak Komersil. Penebar Swadaya, Jakarta.

UPVAP-Unit Pelayanan Veteriner dan Analisis Proksimat. 2016. Kedokteran Hewan. Universitas Airlangga. Surabaya.

Wiryawan, G.K. dan Tim Laboratorium Ilmu dan Teknologi Pakan. 2012. Pengetahuan Bahan Makanan Ternak. Fakultas Peternakan. IPB. Bogor.

Van Soest, P.J. 1982. Nutitional Ecology of The Ruminant. Cornell University Press. Ithaca. New York.

Yunilas. 2009. Bioteknologi Jerami Padi Melalui Fermentasi Sebagai Bahan Pakan Ternak Ruminansia. Karya Ilmiah. Departemen Peternakan Fakultas Pertanian. Universitas Sumatera Utara. Medan. 